\title{
KARAKTER PERTUMBUHAN KACANG TANAH (Arachis hypogaea L.) DENGAN PEMANFAATAN KOMPOS LIMBAH BAGLOG JAMUR DAN KOTORAN DOMBA
}

\section{The Character Growth of Peanut (Arachis hypogaea L.) with Compost Mushroom Baglog and Manure of Lamb}

\author{
Enceng Sobari ${ }^{*}$, Ferdi Fathurohman ${ }^{1}$, dan Muhammad Abdul Hadi \\ ${ }^{1}$ Jurusan Agroindustri, Politeknik Negeri Subang \\ Jl. Arief Rahman Hakim No. 8 (Islamic center) Cigadung Subang Jawa Barat 41212 \\ ${ }^{2}$ Jurusan Agroteknologi, UIN Sunan Gunung Djati Bandung \\ *Alamat Korespondensi: ncesobari@gmail.com
}

\begin{abstract}
ABSTRAK
Penelitian ini bertujuan untuk mengetahui pengaruh pemberian kompos limbah baglog dan pupuk kandang domba terhadap karakter pertumbuhan. Penelitian dilaksanakan pada bulan April sampai Juni 2018 di Jalan Cagak Desa Tambakan, Kabupaten Subang, Jawa Barat. Penelitian menggunakan (RAK) faktorial dengan tiga kali ulangan. Terdapat 2 faktor yang diteliti yaitu kompos limbah baglog jamur dan pupuk kandang domba. Dosis kompos limbah baglog jamur $(\mathrm{K})$ terdiri dari: $\mathrm{K}_{0}=$ tanpa kompos baglog, $\mathrm{K}_{1}=$ kompos baglog $90 \mathrm{~g}$ tanaman $^{-1}, \mathrm{~K}_{0}=$ kompos baglog $120 \mathrm{~g}$ tanaman $^{-1}$. Pupuk kandang domba $(\mathrm{P})$ terdiri dari: $\mathrm{P}_{0}=$ tanpa pupuk domba, $\mathrm{P}_{1}=$ pupuk domba $90 \mathrm{~g}_{\text {tanaman }}^{-1}, \mathrm{P}_{2}=$ pupuk domba $120 \mathrm{~g}$ tanaman ${ }^{-1}$. Pengamatan dilakukan terhadap karakter pertumbuhan tanaman meliputi tinggi tanaman, jumlah daun, indeks luas daun dan bobot kering berangkasan tanaman. Hasil penelitian dosis kompos limbah baglog memberikan respon terbaik pada semua karakter pertumbuhan dan $\mathrm{t}$ bobot kering berangkasan tanaman pada umur 5 MST, 10 MST. Perlakuan pupuk kandang domba memberikan pengaruh paling baik pada umur 14 MST.
\end{abstract}

Kata kunci: Arachis hypogaea L., baglog jamur, kacang tanah, karakter pertumbuhan, pupuk kandang domba

\section{ABSTRACT}

The aim of this research is to know the effect of the compost made of baglog waste and lamb manure on growth character. This research was carried out in April to June 2018 in the Cagak Road Tambakan Village of Subang on West Java. The study used a factorial (Randomized Group Design) with three times repeats. There are two factors that are baglog waste compost and lamb manure. Dose of compost baglog waste compost are ; $K_{0}=$ without baglog waste compost, $K_{1}=90 \mathrm{~g}_{\text {plant }}{ }^{-1}$ baglog waste compost, $K_{0}=120 \mathrm{~g}$ plant ${ }^{-1}$ baglog waste compost. Dose of lamb manure are; $P_{0}=$ without lamb manure, $P_{1}=90 \mathrm{~g}$ plant ${ }^{-1}$ lamb manure, $P_{2}=120 \mathrm{~g}$ plant $^{-1}$ lamb manure. Observations were made to the plant's vegetative characters i.e. plant height, number of leaves, Leave Area Index and the dry weight of plant. The results of research on baglog waste compost doses gave the best response to all growth characters and t-crop dry weight at age 5 MST, 10 MST. The treatment of sheep manure had the best influence at the age of 14 MST.

Key words: Arachis hypogaea L., mushroom baglog waste compost, peanut, growth character, manure of lamb

\section{PENDAHULUAN}

Kebutuhan makanan saat ini semakin meningkat seiring dengan pertumbuhan jumlah penduduk. Hal ini berimbas pada kebutuhan bahan pangan nasional yang semakin tinggi, tetapi tidak diimbangi dengan persediaan bahan pangan yang cukup. Kacang tanah merupakan komoditas industri yang memiliki nilai ekonomi yang cukup tinggi. Kebutuhan kacang tanah untuk industri di Indonesia begitu besar, tapi produksi yang dihasilkan kurang tercukupi. Data produksi kacang tanah di Jawa Barat pada tahun 2013 mencapai $16.85 \mathrm{kuintal} / \mathrm{ha}$, sedangkan pada tahun 2014 mengalami penurunan 
14.76 kuintal/ha (Badan Pusat Statistik Republik Indonesia, 2016).

Penurunan produksi kacang tanah disebabkan faktor kesuburan tanah dan ginofor pada tanaman kacang tanah tidak dapat menembus tanah. Ginofor merupakan bakal calon polong yang akan berkembang jika menembus ke dalam tanah. Kegagalan ginofor yang tidak dapat mencapai tanah disebabkan karena kontur tanah yang keras atau padat sehingga menyulitkan untuk bisa menembus tanah. Salah satu cara yang bisa dilakukan agar ginofor dapat menembus tanah dan berkembang menjadi polong, serta meningkatkan hasil kacang tanah adalah dengan cara pemupukan bahan organik. Upaya untuk meningkatkan produktifitas kacang tanah nasional diantaranya dengan pemberian pupuk kompos (Sembiring dkk., 2014). Peran mikroorganisme dalam proses pembuatan kompos akan melepaskan energi panas dalam proses karbonasi. Pada saat penguraian bahan organik yang sangat aktif, mikroba yang ada di dalam kompos mulai melakukan metabolisme dengan cara menguraikan dan merubah bahan organik menjadi $\mathrm{NH}_{3}{ }^{+}$, $\mathrm{CO}_{2}$, uap air dan panas dengan bantuan oksigen (Hastuti dkk., 2015). Hal ini yang menyebabkan stuktur tanah yang padat menjadi gembur.

Baglog jamur merupakan media tanam jamur yang terbuat dari serbuk gergaji. Limbah tersebut tidak dapat digunakan kembali, sehingga perlu dimanfaatkan sebagai pembuatan kompos. Kompos merupakan pupuk hayati yang dihasilkan dari penguraian bakteri pada bahan organik melalui pengomposan. Kandungan yang terdapat pada limbah jamur mempunyai kandungan kadar air $37 \%$, nitrogen sebesar $0,9 \%$, fosfor sebesar $2 \%$, kalium 8,5\%, dan $\mathrm{C} / \mathrm{N}$ rasio sebesar 37\% (Bellapama dkk., 2015). Kotoran domba berupa limbah yang dihasilkan ternak domba yang dapat digunakan sebagai pupuk untuk tanaman. Kandungan yang terdapat dalam feses domba mengandung banyak mikroorganisme yang berperan sebagai dekomposer. Hasil dekomposer dari kotoran domba tersebut menjadi bahan organik sederhana sehingga dapat diserap oleh tanaman sebagai nutrisi (Hidayati dan Harlia, 2013). Tujuan dari penelitian untuk mengetahui pengaruh limbah baglog jamur menjadi kompos dan kotoran domba sebagai media terhadap karakter pertumbuhan tanaman kacang tanah.

\section{METODE}

Percobaan dilaksanakan di Desa Tambakan Jalan Cagak, Kabupaten Subang, Jawa Barat pada bulan April-Juni 2018. Bahan percobaan menggunakan benih kacang tanah varietas domba, limbah baglog jamur yang dibuat menjadi kompos, 
dan kotoran domba. Metode penelitian menggunakan Rancangan Acak Kelompok (RAK) faktorial. Faktor pertama yaitu dosis kompos baglog sebanyak tiga taraf perlakuan dan faktor kedua yaitu dosis pupuk domba dengan dengan tiga taraf perlakuan yang di ulang sebanyak tiga kali. Dosis kompos baglog $(\mathrm{K})$ terdiri dari $\mathrm{K}_{0}=$ tanpa kompos baglog, $\mathrm{K}_{1}=$ kompos baglog $90 \mathrm{~g}$ tanaman- ${ }^{1}, \mathrm{~K}_{2}=$ kompos baglog $120 \mathrm{~g}$ tanaman- ${ }^{1}$. Pupuk domba $(\mathrm{P})$ terdiri dari $\mathrm{P}_{0}$ $=$ tanpa pupuk domba, $\mathrm{P}_{1}=$ pupuk domba $90 \mathrm{~g}$ tanaman- ${ }^{1}, \mathrm{P}_{2}=$ pupuk domba $120 \mathrm{~g}$ tanaman- ${ }^{1}$. Jika variabel percobaan memperlihatkan berpengaruh yang nyata selanjutnya dilakukan dengan Uji Jarak Berganda Duncan taraf kesalahan 5\%.

Ukuran lahan bedengan percobaan yang digunakan adalah 80x60 cm, jarak antar bedengan $40 \mathrm{~cm}$, dan jarak antar ulangan $50 \mathrm{~cm}$. Jumlah tanaman untuk tiap bedengan 8 tanaman menggunakan jarak tanam 20x30 cm. Karakter morfologi yang diamati selama percobaan meliputi tinggi tanaman, jumlah daun tanaman, Indeks Luas Daun (ILD), dan Bobot Kering Berangkasan Tanaman.

\section{HASIL DAN PEMBAHASAN}

\section{Tinggi Tanaman}

Pertumbuhan tanaman kacang tanah varietas domba bertipe erect, yaitu memiliki 5 batang utama dengan 1 batang di tengah tumbuh menjulang ke atas dan 4 lainnya memiliki batang yang cenderung tegak. Kacang tanah dengan tipe tegak memiliki percabangan yang tumbuh agak lurus ke atas dan umurnya relatif genjah (Kasno dan Harnowo, 2014). Pengukuran tinggi tanaman dilakukan dengan mengukur batang tengah tanaman (Gambar 1).

Hasil evaluasi karakter pertumbuhan berdasarkan tinggi tanaman yang diamati pada umur 10 MST menunjukkan pemberian kompos baglog dan pupuk domba berpengaruh pada variabel tersebut. Pada umur 5 MST terjadi pengaruh interaksi dari kedua perlakuan terhadap tinggi tanaman kacang tanah (Tabel 1), tetapi pada umur 14 MST hanya pupuk domba yang memberikan pengaruh. Hal ini disebabkan akibat ketersedian unsur nitrogen yang tersedia pada awal pertumbuhan kacang tanah belum optimal dimanfaatkan oleh bakteri rhizobium yang ada pada akar kacang tanah. Peranan rhizobium dalam tanah membantu memfiksasi nitrogen agar mudah diserap tanaman bila menginfeksi akar tanaman yang membentuk bintil akar (Maggioni et al., 2002). Peranan nitrogen bagi tanaman berfungsi sebagai penyusun protoplasma, molekul khlorofil, asam nukleat, dan asam amino yang merupakan penyusun protein (Ramdana dan Prayudyaningsih, 2015). 


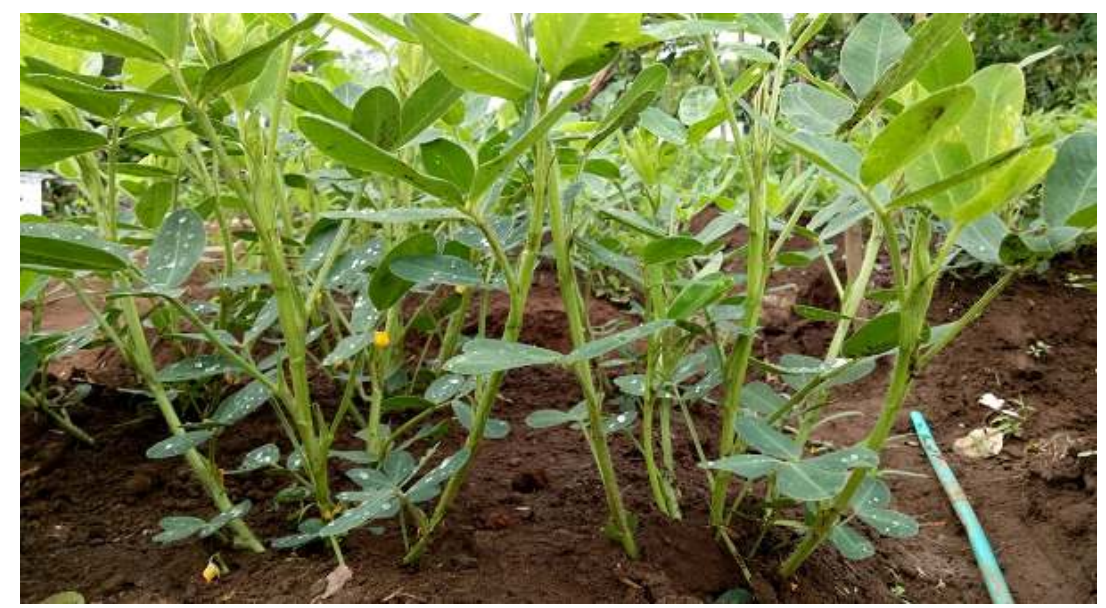

Gambar 1. Tanaman Kacang Tanah Varietas Domba

Tabel 1. Analisis ragam karakter pertumbuhan tanaman kacang tanah pada umur 5, 10, dan 14 MST

\begin{tabular}{lccccccccc}
\hline & \multicolumn{3}{c}{ Tinggi tanaman(cm) } & \multicolumn{3}{c}{ Jumlah Daun (helai) } & \multicolumn{4}{c}{ Indeks Luas Daun } \\
Perlakuan & 5 & 10 & 14 & 5 & 10 & 14 & 5 & 10 & 14 \\
& MST & MST & MST & MST & MST & MST & MST & MST & MST \\
\hline $\begin{array}{l}\text { Kompos } \\
\text { Baglog (K) }\end{array}$ & $0,65^{\text {th }}$ & $4,58^{*}$ & $2,12^{\text {th }}$ & $4,70^{*}$ & $5,21^{*}$ & $2,97^{\text {th }}$ & $4,72^{*}$ & $5,21^{*}$ & $2,97^{\text {tn }}$ \\
$\begin{array}{l}\text { Pupuk } \\
\text { Domba (P) }\end{array}$ & $0,02^{\text {tn }}$ & $3,78^{*}$ & $5,02^{*}$ & $1,98^{\text {tn }}$ & $2,46^{\text {th }}$ & $6,91^{*}$ & $1,98^{\text {tn }}$ & $2,45^{\text {tn }}$ & $6,90^{*}$ \\
$\begin{array}{l}\text { Interaksi } \\
\text { K x P }\end{array}$ & $3,20^{*}$ & $1,97^{\text {tn }}$ & $0,69^{\text {tn }}$ & $3,80^{*}$ & $3,72^{*}$ & $2,51^{\text {tn }}$ & $3,80^{*}$ & $3,72^{*}$ & $2,51^{\text {tn }}$ \\
\hline Keteng & & & & & & & & & \\
\hline
\end{tabular}

Keterangan: $\mathrm{tn}=$ tidak berpengaruh nyata pada taraf 5\%; $*$ = berpengaruh nyata pada taraf $5 \%$; MST $=$ Minggu Setelah Tanam.

\section{Jumlah Daun}

Daun tanaman kacang kedelai memiliki tipe majemuk atau tergolong kedalam Narrow-elliptic, terdiri dari empat helai anak daun berbentuk bulat memanjang dan berwarna hijau tua (Stalker et al., 2016) seperti yang ditunjukkan pada Gambar 2.

Hasil analisis (Tabel 1) memperlihatkan kompos baglog jamur berpengaruh pada perlakuan 5 MST dengan nilai kisaran 4,70 - 6,91. Hal ini mengindikasikan bahwa perlakuan kompos baglog mampu mempengaruhi jumlah daun pada tanaman kacang tanah, tetapi pemberian pupuk domba pada 5 MST dan 10 MST tidak berbeda seperti yang ditunjukkan pada Tabel 1. Sebagaimana yang dinyatakan (Sarawa et al., 2014), bahwa pemberian pupuk kandang pada umur 18, 24, dan 30 HST berpengaruh terhadap jumlah daun terbentuk. Hasil tersebut dapat diasumsikan bahwa pemberian pupuk domba pada umur awal pertumbuhan atau fase vegetatif mempengaruhi jumlah daun tanaman kacang tanah. 


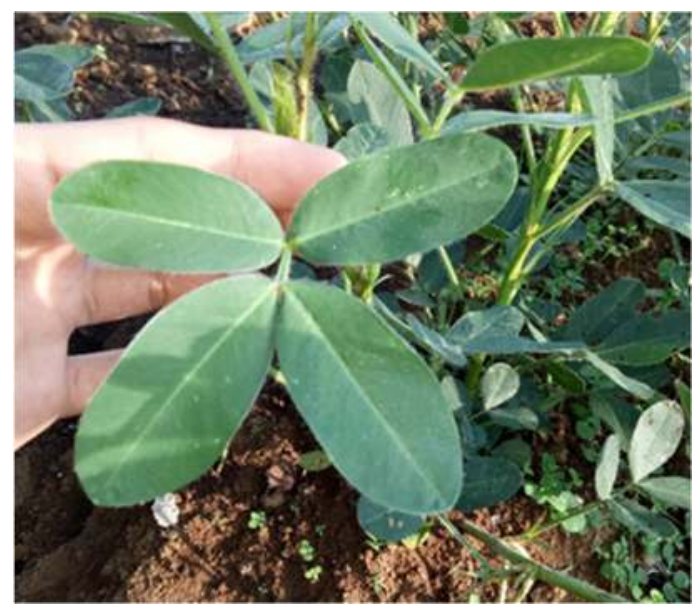

Gambar 2. Daun kacang tanah varietas Domba

Tabel 2. Analisis Ragam Bobot Kering Berangkasan Tanaman- ${ }^{1}$ Kacang Tanah

\begin{tabular}{lc}
\hline Perlakuan & Bobot Berangkasan Tanaman $(\mathrm{g})$ \\
\hline Kompos Baglog $(\mathrm{K})$ & $5,43^{*}$ \\
Pupuk Domba $(\mathrm{P})$ & $2,42^{\text {th }}$ \\
K x P & $1,50^{\text {th }}$ \\
\hline
\end{tabular}

Keterangan: th $=$ tidak berpengaruh nyata pada taraf 5\%; $*$ berpengaruh nyata pada taraf $5 \%$; MST $=$ Minggu Setelah Tanam.

\section{Indeks Luas Daun (ILD)}

Pemberian kompos baglog pada umur 5 MST dan 10 MST berbeda nyata pada variabel ILD, kecuali pada umur 14 MST, tetapi sebaliknya variabel ILD berbeda nyata memasuki umur 14 MST pada pemberian pupuk domba. Hal ini disebabkan efektifitas kompos dan pupuk domba dipengaruhi oleh ketersediaan air dalam tanah. Kadar air tanah yang semakin rendah maka akan mempengaruhi pertumbuhan tanaman menjadi terhambat. Air sangat berperan dalam melarutkan hara yang tersedia dan ditranslokasikan ke seluruh bagian tanaman melalui proses reaksi biokimia dalam sel tanaman (Manurung dkk., 2015). Kadar air memiliki peran yang kritis dalam rekayasa pengomposan, sebab dekomposisi material organik sangat tergantung kepada tersedianya kandungan air (Hastuti et al., 2015).

\section{Bobot Kering Berangkasan Tanaman}

Berdasarkan data analisis yang diperoleh pada Tabel 2, terlihat bahwa bobot kering berangkasan tanaman memberikan pengaruh nyata pada pemberian kompos baglog. Pemberian pupuk domba tidak berpengaruh pada bobot kering berangkasan disebabkan faktor lingkungan. Faktor lingkungan dapat mempengaruhi penampilan suatu tanaman (Sobari dan Wicaksana, 2017) diantaranya disebabkan karena gulma yang tumbuh dari bekas kotoran domba yang dapat tumbuh kembali. Keberadaan gulma pada saat awal muncul dapat mempengaruhi bobot berangkasan per 
tanaman, karena adanya kompetisi dalam perebutan unsur hara dan air (Sobari dan Fathurohman, 2017).

\section{KESIMPULAN}

1. Hasil analisis mengindikasikan bahwa perlakuan kompos baglog jamur pada umur 5 MST dan 10 MST mampu mempengaruhi semua parameter pertumbuhan. Pemberian kotoran domba memberikan respon terbaik pada semua karakter pada umur 14 MST.

2. Pemberian kompos baglog jamur memperlihatkan pengaruh terbaik terhadap pertumbuhan kacang tanah berdasarkan karakter bobot kering berangkasan.

3. Informasi mengenai pemanfaatan kompos limbah baglog dan kotoran domba dapat digunakan sebagai bahan pertimbangan pemupukan secara organik.

\section{UCAPAN TERIMAKASIH}

Penelitian ini didanai oleh Direktorat Riset dan Pengabdian Masyarakat, Direktorat Jenderal Penguatan Riset dan Pengembangan Kementerian Riset, Teknologi, dan Pendidikan Tinggi melalui Program Hibah Penelitian Dosen Pemula (PDP).

\section{DAFTAR PUSTAKA}

Badan Pusat Statistik Republik Indonesia. 2016. Produksi, luas panen dan produktivitas padi dan palawija di Indonesia. Pusat Data dan Sistem Informasi Pertanian Kementerian Pertanian Republik Indonesia, Jakarta.

Bellapama, I. A., K. Hendarto dan R. A. D. Widyastuti. 2015. Pengaruh pemupukan organik limbah baglog jamur dan pemupukan takaran NPK terhadap pertumbuhan dan produksi pakchoy (Brassica chinensis L.). J. Agrotek Tropika, 3(3): 327 - 331.

Hastuti, S. M., G. Samudro dan S. Sumiyati. 2015. Pengaruh ukuran bahan dan metode pengomposan terhadap ph, suhu dan kadar air pada pengomposan sampah daun. Seminar Nasional Teknologi Industri Hijau 2, 18 Mei 2017, Semarang.

Hidayati, Y. A., Tb. Benito A.K., dan E. Harlia. 2013. Analisis jumlah bakteri dan identifikasi bakteri pada pupuk cair dari feses domba dengan penambahan Saccharomyces cerevisiae. Jurnal Ilmu Ternak, 13(2): $1-3$.

Kasno, A. dan D. Harnowo. 2014. Karakteristik varietas unggul kacang tanah dan adopsinya oleh petani. Iptek Tanaman Pangan, 9(1): 13 23.

Maggioni, L., S. Georgiev dan E. Lipman. 2002. Arachis genetic resources in Europe. Ad hoc meeting, 15-16 November 2002, Plovdiv, Bulgaria.

Manurung, Y. C., A. S. Hanafiah dan P. Marbun. 2015. Pengaruh berbagai kadar air tanah pada efektivitas mikoriza arbuskula terhadap pertumbuhan dan serapan hara bibit karet (Hevea brassiliensis Muell. Arg.) di rumah kasa. Jurnal Online Agroekoteknologi, 3(2): 465 - 475.

Ramdana, S. dan R. Prayudyaningsih. 
2015. Rhizobium: pemanfaatannya sebagai bakteri penambat nitrogen. Jurnal Info Teknis EBONI, 12(1): 51 -64 .

Sarawa, M. J. Arma dan M. Mattola. 2014. Pertumbuhan tanaman kedelai (Glycine Max L. Merr) pada berbagai interval penyiraman dan takaran pupuk kandang. Jurnal Agroteknos, 4(2): $78-86$.

Sembiring, M., R. Sipayung dan F.E. Sitepu. 2014. Pertumbuhan dan produksi kacang tanah dengan pemberian kompos tandan kosong kelapa sawit pada frekuensi pembumbunan yang berbeda. Jurnal Online Agroekoteknologi, 2(2): 598 606.
Sobari, E. dan F. Fathurohman. 2017. Efektivitas penyiangan terhadap hasil tanaman wortel (Daucus carota L.) lokal Cipanas Bogor. Jurnal Biodjati, 1(2): 1 - 8 .

Sobari, E. dan N. Wicaksana. 2017. Keragaman genetik dan kekerabatan genotip kacang bambara (Vigna subteranea L.) lokal Jawa Barat. Jurnal Agro, IV(2), 90 - 96.

Stalker, H. T., S. P. Tallury, G. R. Seijo and S. C. Leal-Bertioli. 2016. Biology, Speciation, and Utilization of Peanut Species. In H. Thomas Stalker \& Richard F. Wilson (Eds.), Peanuts Genetics, Processing, and Utilization (pp. 1 - 478). 